\title{
HUBUNGAN PENGUNGKAPAN CORPORATE SOCIAL RESPONSIBILITY DAN PRICE TO BOOK VALUE DENGAN RETURN ON ASSET SEBAGAI VARIABEL MODERASI
}

\author{
Omi Pramiana
}

STIE PGRI Dewantara Jombang

Email: omi.pramiana@gmail.com

\section{ARTICLE INFO}

\section{Article History}

Received 23 Dec 2018

Revised 10 January 2019

Accepted 31 January 2019

JEL Classification

M14, M41

Kata kunci:

Corporate

Responsibility,

Return on Asset,

Price to Book Value
Social

\section{Abstrak}

Sebuah perusahaan didirikan memiliki tujuan yang jelas. Salah satu tujuan perusahaan adalah memaksimalkan nilai perusahaan yang tercermin pada harga sahamnya. Penelitian ini bertujuan untuk membuktikan pengaruh Corporate social responsibility terhadap price book value dengan profitabilitas sebagai variabel moderasi. Penelitian ini menggunakan Moderating Regression Analysis karena diantara variabel independent dengan variabel dependep terdapat variabel moderating yang mempengaruhi. Hasil penelitian menjelaskan bahwa tidak terdapat pengaruh Corporate Social Responsibility Disclosure Index terhadap Price Book Value dengan $t$ hitung Corporate Social Responsibility Disclosure Index sebesar 1.393 dan t tabel sebesar 1.703 sehingga t hitung lebih kecil dari t tabel (1.393 $<1.703$ ) serta nilai signifikasi sebesar 0.175 lebih besar dari $0,05(0.175>0,05)$ artinya naik turunnya Corporate Social Responsibility Disclosure Index tidak mempengaruhi Price Book Value. Interaksi antara CSR dan prosentase Return on Asset berpengaruh signifikan terhadap nilai perusahaan dengan nilai $\mathrm{t}$ hitung sebesar 2.180 dan nilai signifikasi sebesar 0.038 artinya Return on Asset sebagai variabel moderating dapat meningkatkan Price Book Value saat pengungkapan CSR meningkat.

\section{PENDAHULUAN}

Sebuah perusahaan didirikan dengan memiliki tujuan yang jelas. Pertama adalah untuk mencapai keuntungan maksimal atau laba yang sebesar-besarnya. Kedua adalah ingin memakmurkan pemilik perusahaan atau para pemilik saham. Sedangkan tujuan perusahaan yang ketiga adalah memaksimalkan nilai perusahaan yang tercermin pada harga sahamnya. Ketiga tujuan perusahaan tersebut sebenarnya secara substansial tidak banyak berbeda. Hanya saja penekanan yang ingin dicapai oleh masing- masing perusahaan berbeda antara yang satu dengan yang lainnya (Martono dan Harjito, 2012).

Return on asset adalah salah satu rasio profitabilitas yang dimaksudkan untuk mengukur kemampuan perusahaan atas keseluruhan dana yang ditanamkan dalam aktivitas yang digunakan untuk aktivitas operasi perusahaan dengan tujuan menghasilkan laba dengan memanfaatkan aset yang dimilikinya. ROA merupakan rasio yang penting di antara rasio profitabilitas yang ada. ROA yang negatif disebabkan laba 
perusahaan dalam kondisi negatif pula atau rugi. Hal ini menunjukkan kemampuan dari modal yang diinvestasikan secara keseluruhan belum mampu untuk menghasilkan laba (Ang, 2007).

Pada saat ini beberapa harga saham perbankan hingga penutupan sesi I hari ini, Rabu 3 Juni 2015 menurun cukup tajam. Beberapa di antaranya PT Bank Negara Indonesia Tbk (BBNI) anjlok 4,1 persen menjadi Rp6.375, PT Bank Rakyat Indonesia Tbk (BBRI) turun 3,2 persen menjadi Rp11.350, PT Bank Mandiri (Persero) Tbk (BMRI) turun 1,2 persen menjadi Rp10.575, PT Bank Central Asia Tbk (BBCA) turun 2,7 persen menjadi Rp13.600 dan PT Bank Tabungan Negara Tbk (BBTN) turun 2,6 persen menjadi Rp1.145. Menurut Jayden Vantarakis, analis CLSA Indonesia dalam risetnya menyatakan bahwa sektor perbankan sedang mengalami performa yang kurang memuaskan (underperform) (Rahmayanti, 2015).

Undang-Undang No. 40 Tahun 2007 tentang Perseroan Terbatas diterbitkan dan mewajibkan perseroan yang bidang usahanya di bidang atau terkait dengan bidang sumber daya alam untuk melaksanakan tanggung jawab sosial dan lingkungan. Undang-Undang tersebut (Pasal 66 ayat 2c) mewajibkan semua perseroan untuk melaporkan pelaksanaan tanggung jawab sosial dan lingkungan dalam laporan tahunan. Pelaporan tersebut merupakan pencerminan dari perlunya akuntabilitas perseroan atas pelaksanaan tanggung jawab sosial dan lingkungan, sehingga para stakeholders dapat menilai pelaksanaan kegiatan tersebut. Corporate social responsibility dalam undang-undang tersebut (Pasal 1 ayat 3) dikenal dengan istilah tanggung jawab sosial dan lingkungan yang diartikan sebagai komitmen perseroan untuk berperan serta dalam pembangunan ekonomi berkelanjutan guna meningkatkan kualitas kehidupan dan lingkungan yang bermanfaat, baik bagi perseroan sendiri, komunitas setempat, maupun masyarakat pada umumnya.
Handriyani dan Andayani (2013) menjelaskan bahwa CSR berpengaruh positif terhadap nilai perusahaan. Ini mengindikasikan bahwa dengan tingginya tingkat pengungkapan tanggungjawab sosial (CSR) akan membuat perusahaan memiliki citra positif di masyarakat dan khususnya di kalangan bisnis, sehingga perusahaan akan mendapatkan respons dari masyarakat akan eksistensinya di dunia bisnis yang nantinya akan meningkatkan nilai perusahaan. Namun Profitabilitas tidak mampu memoderasi hubungan CSR terhadap nilai perusahaan. CSR tidak dapat meningkatkan nilai perusahaan pada saat profitabilitas perusahaan tinggi, dan sebaliknya CSR juga tidak dapat menurunkan nilai perusahaan pada saat profitabilitas perusahaan rendah.

Permasalahan dengan adanya penurunan harga saham perbankan mendorong identifikasi masalah bagaimana pengaruh corporate social responsibility terhadap price book value dan apakah return on asset dapat menjadi variabel moderasi

Berdasarkan latar belakang diatas identifikasi masalahnya adalah bagaimana pengaruh Corporate social responsibility terhadap price book value dengan return on asset sebagai variabel moderasi? Adapun tujuan dilakukannya penelitian ini adalah untuk mengetahui bagaimana pengaruh Corporate social responsibility terhadap price book value dan apakah apakah return on asset dapat menjadi variabel moderasi

\section{KAJIAN LITERATUR}

\section{Corporate Social Responsibility}

Menurut The World Business Council for Sustainable Development (WBCSD) mendefinisikan bahwa CSR adalah komitmen bisnis untuk berkontribusi dalam ekonomi berkelanjutan, bekerja dengan karyawan perusahaan, keluarga karyawan tersebut, masyarakat secara keseluruhan dalam rangka meningkatkan kualitas kehidupan dengan cara yang bermanfaat bagi bisnis sendiri maupun pembangunan (Rahman, 2009). 
Untuk mengetahui hasil pelaporan CSR perusahaan maka penulis menggunakan acuan pengungkapan Key Succes Factors for Performance by Nor Hadi (2009) yang terdiri dari beberapa dimensi pengungkapan, yaitu environmental, energy, community, employee, product dan bentuk lainnya.

1. Envinronmental adalah sebuah bentuk tanggung jawab yang diberikan perusahaan kepada sekitar dengan memperhatikan lingkungan di sekitar perusahaan berdiri

2. Energy adalah terkait dengan bagaimana seharusnya perusahaan menjaga konsumsi energi bumi pada operasional perusahaan, terutama pada energi yang tidak dapat diperbaharui lagi.

3. Community adalah bentuk tanggung jawab yang ditujukan pada pengabdian masyarakat sekitar dengan cara membantu membangun sarana dan prasarana.

4. Employee terkait dengan bagaimana seharusnya perusahaan memperhatikan kepentingan karyawan dan meningkatkan kepuasan kebutuhannya.

5. Product adalah komitmen perusahaan dalam menjaga kualitas produk yang mereka hasilkan. Bentuk tanggung jawab yang terakhir adalah bagaimana perusahaan berkomitmen terhadap supplier, bankers, marketforce, government, shareholder, dan director.

Pengungkapan CSR merupakan data yang diungkap oleh perusahaan berkaitan dengan aktivitas sosialnya. Daftar pengungkapan pertanggungjawaban sosial yang digunakan dalam penelitian ini adalah menggunakan daftar pengungkapan yang terdapat dalam penelitian oleh Nor Hadi (2009) yang disebut Key Succes for Social Performance Measurement. Pengungkapan CSR diukur dengan menggunakan skala Guttman, Sugiyono (2008:137), yaitu:

Score 0: Jika perusahaan tidak mengungkapkan item pada daftar pertanyaan.

Score 1: Jika perusahaan mengungkapkan item pada daftar pertanyaan
Peneliti menggunakan 2 dimensi dari metode pengukuran oleh Nor Hadi yaitu community dan empoyee yang berisi 41 indikator item pengungkapan yang mungkin dilakukan oleh objek sampel, sehingga peneliti dapat mengetahui seberapa besar perusahaan melakukan tanggung jawab sosial kepada masyarakat.

Selain itu pada penelitian ini tidak memasukkan bentuk pengungkapan yang lain seperti diungkapkan oleh Nor Hadi (2009) yang disebut Key Succes for Social Performance Measurement. Adapun alasannya adalah peneliti menyesuaikan bentuk tanggung jawab yang mungkin diungkapkan oleh sampel penelitian yaitu perusahaan perbankan.

Pengukuran kemudian dilakukan berdasarkan indeks berupa indeks pengungkapan masing-masing perusahaan yang dihitung melalui jumlah item yang sesungguhnya diungkapkan perusahaan dengan jumlah semua item yang mungkin diungkapkan. Rumus perhitungan indeks pengungkapan pertanggungjawaban sosial (Corporate Social Responsibility Disclosure Index-CSRDI) adalah sebagai berikut:

$$
\text { CSRDI }=\frac{\Sigma x i j}{n j}
$$

Keterangan:

CSRDI : Corporate Social Responsibility Disclosure Index perusahaan

$X_{i j} \quad$ : item yang diungkapkan

$\mathrm{n}_{\mathrm{j}} \quad$ : jumlah item yang digunakan

\section{Return on Asset}

Munawir (2012) menjelaskan bahwa Return on Asset merefleksikan seberapa banyak perusahaan telah memperoleh hasil atas sumber daya keungan yang ditanamkan oleh perusahaan.

Menurut Munawir (2012) ROA memiliki beberapa manfaat yang antara lain: 
1. Jika perusahaan telah menjalankan praktik akuntansi dengan baik maka dengan analisis ROA dapat diukur efisiensi penggunaan modal yang menyeluruh dan sensitif terhadap setiap hal yang mempengaruhi keadaan keuangan perusahaan.

2. Dapat diperbandingkan dengan rasio industry sehingga dapat diektahui posisi perusahaan terhadap industry. Hal ini merupakan salah satu langkah dalam perencanaan strategi.

3. Selain berguna untuk kepentingan control, analisis ROA jugsa berguna untuk kepentingan perencanaan.

Menurut Harahap (2012) menyatakan bahwa rasio profitabilitas menggambarkan kemampuan perusahaan mendapatkan laba melalui semua kemampuan dan sumber yang ada seperti kegiatan penjualan, kas, modal, jumlah karyawan, jumlah cabang dan sebagainya.

Return On Asset $=\frac{\text { I aha Rersih Sehelum Pajak }}{\text { Total Aktiva }} \times 100 \%$

\section{Price Book Value}

Price to book value adalah salah satu indikator yang digunakan investor untuk melihat keadaan/posisi finansial suatu perusahaan. PBV digunakan untuk menilai apakah suatu perusahaan memiliki masa depan cerah untuk berinvestasi. Price to book value (rasio harga terhadap nilai buku) adalah rasio yang menggambarkan seberapa besar pasar menghargai nilai buku saham suatu perusahaan (Darmadji dan Fakhruddin, 2001: 141). Semakin tinggi rasio ini menjelaskan bahwa pasar percaya terhadap prospek/masa depan perusahaan tersebut. Price to book value Dapat dirumuskan sebagai berikut:

Price Book Value $=\frac{\text { Harga Per Saham }}{\text { Nilai. Buku Per Saham (BV) }} \times 100 \%$

\section{Kerangka Berfikir}

Berdasarkan teori dan penelitian terdahulu, dalam penelitian ini kerangka berpikir sebagai berikut:

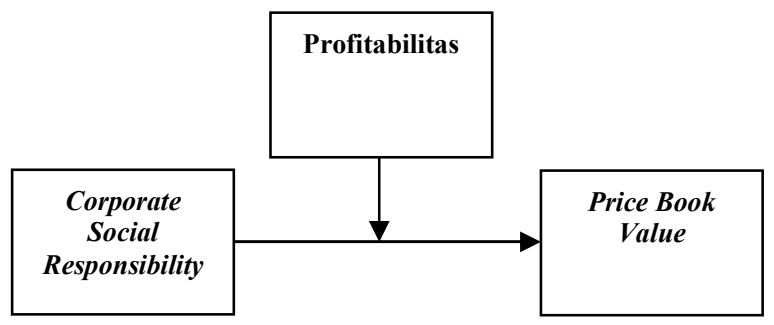

Gambar 1. Kerangka Berikir

Hipotesis

Berdasarkan teori dan penelitian terdahulu, dalam penelitian ini hipotesis sebagai berikut:

$\mathrm{H}_{1}=$ Terdapat pengaruh Corporate Social Responsibility terhadap price book value

$\mathrm{H}_{2}=$ Profitabilitas memperkuat atau memperlemah pengaruh Corporate Social Responsibility terhadap price book value.

\section{METODOLOGI PENELITIAN}

Penelitian ini menggunakan Moderating Regression Analysis karena diantara variabel independent dengan variabel dependep terdapat variabel moderating yang mempengaruhi. Dalam penelitian ini terdiri dari tiga variabel yakni variabel independent Corporate Social Responsibility, variabel Return on Asset dan variabel dependent price book value.

\section{Populasi dan Sampel}

Populasi yang ada di dalam penelitian ini adalah 30 laporan keuangan Bank Umum Swasta Nasional Devisa. Metode pemilihan sampel yang digunakan dalam penelitian ini adalah metode purposive sampling. Adapun kriteria pemilihan sampel dalam penelitian ini adalah:

1. Bank Umum Swasta Nasional Devisa memiliki laporan tahunan tahun 2013 s.d. 
2015, memiliki data keuangan yang lengkap dan telah diaudit.

2. Bank Umum Swasta Nasional Devisa yang melakukan pengungkapan CSR seperti dimensi pengukuran yang peneliti pilih yaitu community dan employee.

Dari kriteria tersebut sampel yang digunakan adalah sebanyak laporan keuangan dari 10 Bank Umum Swasta Nasional Devisa yang terdiri dari:

Tabel 1. Sampel Penelitian

\begin{tabular}{cl}
\hline No. & \multicolumn{1}{c}{ Bank } \\
\hline 1. & Bank Artha Graha Internasional \\
\hline 2. & Bank Bukopin \\
\hline 3. & Bank Central Asia \\
\hline 4. & Bank Cimb Niaga \\
\hline 5. & Bank ICB Bumiputera \\
\hline 6. & Bank Internasional Indonesia \\
\hline 7. & Bank Mega \\
\hline 8. & Bank Sinarmas \\
\hline 9. & Bank OCBC NISP \\
\hline 10. & Bank Swadesi \\
\hline
\end{tabular}

HASIL PENELITIAN DAN PEMBAHASAN

Analisis Data

1. Deskriptif Data

Tabel 2. Deskripsi Data

\begin{tabular}{lrrr}
\hline \multicolumn{1}{c}{ Keterangan } & Min. & Max. & Mean \\
\hline CSR Disclosure & 0.12 & 0.37 & 0.2363 \\
\hline Return on Asset & 0.01 & 2.83 & 1.3783 \\
\hline Price Book Value & 0.30 & 4.33 & 1.4230
\end{tabular}

Berdasarkan pengujian statistik pada tabel 2 akan dijelaskan sebagai berikut:

a. Corporate Social Responsibility Disclosure Index mempunyai nilai minimum sebesar 0.12 pada Bank Mega dan Bank Swadesi tahun 2015, nilai maksimum sebesar 0.37 pada Bank OCBS NISP pada tahun 2014. Nilai ratarata (mean) sebesar 0.2363 artinya 0.2363 atau $24 \%$ keuntungan perusahaan dikeluarkan untuk kegiatan CSR b. Return on Asset mempunyai nilai minimum sebesar 0.01 pada Bank ICB Bumiputera tahun 2015, nilai maksimum sebesar 2.83 pada Bank Central Asia pada tahun 2014. Nilai ratarata (mean) sebesar 1.3783 artinya return on asset di Bank Umum Swasta Nasional Devisa yang terdaftar di Bursa Efek Indonesia maksimal terbesar 1.3783 dan minimal 0.01 dengan ratarata return on asset sebesar 1.3783.

c. Price Book Value mempunyai nilai minimum sebesar 0.30 pada Bank Artha Graha Internasional tahun 2015, nilai maksimum sebesar 4.33 pada Bank Central Asia pada tahun 2014. Nilai ratarata (mean) sebesar 1.4230 artinya 1.4230 pasar menghargai nilai buku saham Bank Umum Swasta Nasional Devisa yang terdaftar di Bursa Efek Indonesia. price book value menunjukkan nilai dari berbagai asset yang dimiliki oleh perusahaan termasuk surat berharga yang dikeluarkannya dan untuk perusahaan go public, nilai perusahaan dapat tercermin melalui harga sahamnya.

2. Persamaan Regresi

Tabel 3. Persamaan Regresi

\begin{tabular}{lcr}
\hline \multirow{2}{*}{ Variabel } & \multicolumn{2}{c}{ Unstandardized Coef. } \\
\cline { 2 - 3 } & B & Std. Error \\
\hline PBV & 0.478 & 0.521 \\
\hline CSR & 2.781 & 1.996 \\
\hline ROA & 1.412 & 0.266 \\
\hline CSRxROA & 2.276 & 1.044 \\
\hline
\end{tabular}

Dari Tabel 3, maka didapatkan hasil persamaan sebagai berikut:

$Y=\alpha+\beta_{1} X_{1}+\beta_{2} M+\beta_{3} X_{1} * M+\varepsilon$

$Y=0.478+2.781 C S R+1 . R O A+$ 2.276CSR*ROA

Persamaan regresi tersebut memiliki makna: 
a. Price Book Value adalah sebesar 0.478 artinya jika semua variabel independen dianggap konstan maka Price Book Value adalah sebesar -0.478 .

b. Corporate Social Responsibility Disclosure Index mempunyai koefisien regresi dengan arah positif sebesar 2.781. Jika diasumsikan variabel independen lain konstan, hal ini berarti setiap peningkatan Corporate Social Responsibility Disclosure Index sebesar 1 persen maka Price Book Value akan mengalami peningkatan sebesar 2.781

c. Return on Asset mempunyai koefisien regresi dengan arah positif sebesar 1.412. Jika diasumsikan variabel independen lain konstan, hal ini berarti setiap peningkatan Return on Asset sebesar 1 persen Price Book Value akan mengalami peningkatan sebesar 1.412.

3. Uji Partial (Uji t)

Tabel 4. Uji Partial (Uji t)

\begin{tabular}{lcc}
\hline \multirow{2}{*}{ Variabel } & \multicolumn{2}{c}{ Unstandardized Coef. } \\
\cline { 2 - 3 } & $\mathbf{t}$ & Sig. \\
\hline PBV & 0.918 & 0.367 \\
\hline CSR & 1.393 & 0.175 \\
\hline ROA & 5.318 & 0.000 \\
\hline CSRxROA & 2.180 & 0.038 \\
\hline
\end{tabular}

Berdasarkan hasil olah data menunjukkan $\mathrm{t}$ hitung Corporate Social Responsibility Disclosure Index sebesar 1.393 dan t tabel sebesar 1.703 sehingga $t$ hitung lebih kecil dari t tabel (1.393 < 1.703). Nilai signifikasi sebesar 0.175 lebih besar dari 0,05 $(0.175>0,05)$ artinya tidak signifikan. Dapat disimpulkan bahwa tidak terdapat pengaruh Corporate Social Responsibility Disclosure Index terhadap Price Book Value.

4. Uji Koefisien Determinasi $\left(R^{2}\right)$

Hasil nilai R-Square pada tabel Model Summary ${ }^{b}$ sebesar 0,593. Hal ini berarti bahwa 59.3\% variabel dependen yaitu Price Book Value dipengaruhi oleh variabel independen yaitu Corporate Social Responsibility Disclosure Index dan Return on Asset, sedangkan sisanya sebesar $40.7 \%$ Price Book Value dipengaruhi oleh variabel atau sebab-sebab lainnya diluar model.

5. Uji Variabel Moderasi

Berdasarkan tabel 3. terlihat jelas bahwa variabel CSR dikalikan Return on Asset memberikan koefisien 2.180 dan signifikasi 0.038 yang berarti variabel Return on Asset merupakan moderator antara CSR dan Price Book Value.

\section{Pembahasan}

\section{Pengaruh Corporate Social Responsibility} Disclosure Index Terhadap Price Book Value

Berdasarkan hasil uji parsial menunjukkan bahwa tidak terdapat pengaruh Corporate Social Responsibility Disclosure Index terhadap Price Book Value dengan $\mathrm{t}$ hitung Corporate Social Responsibility Disclosure Index sebesar 1.393 dan t tabel sebesar 1.703 sehingga t hitung lebih kecil dari t tabel $(1.393<1.703)$ serta nilai signifikasi sebesar 0.175 lebih besar dari 0,05 (0.175 > $0,05)$ artinya naik turunnya Corporate Social Responsibility Disclosure Index tidak mempengaruhi Price Book Value.

Hal ini terjadi dikarenakan banyak Bank Umum Swasta Nasional Devisa yang terdaftar di Bursa Efek Indonesia yang menganggarkan dana CSR cukup rendah sedangkan tingkat keuntungan yang diperoleh perusahaan tergolong besar. Sehingga keuntungan tidak dapat membuktikan pengaruhnya di dalam hubungan CSR dan nilai perusahaan. Pengungkapan CSR hanya menjadi alat untuk memenuhi kewajiban untuk memenuhi UU No 40 tahun 2007. Hal ini membuktikan bahwa perusahaan yang lebih luas mengungkapkan informasi tanggung jawab sosialnya akan memiliki nilai perusahaan yang tinggi. 


\section{Return on Asset Memperkuat atau Memperlemah Corporate Social Responsibility (CSR) terhadap Price Book Value}

Berdasarkan olah data Moderating Regression Analysis menunjukkan bahwa interaksi antara CSR dan prosentase Return on Asset berpengaruh signifikan terhadap nilai perusahaan dengan nilai $t$ hitung sebesar 2.180 dan nilai signifikasi sebesar 0.038 artinya Return on Asset sebagai variabel moderating dapat meningkatkan Price Book Value saat pengungkapan CSR meningkat.

Manajer yang sekaligus pemegang saham akan meningkatkan Price Book Value karena dengan meningkatkan Price Book Value, maka nilai kekayaannya sebagai pemegang saham juga akan meningkat. Dengan Price Book Value akan menarik minat investor dalam berinvestasi. Akan tetapi, investor tidak ingin berisiko dalam penanaman modalnya di suatu perusahaan. Investor lebih cenderung memilih perusahaan yang telah mengungkapkan tanggung jawab sosialnya dalam suatu laporan tahunan.

Dalam UU Perseroan Terbatas No. 40 Tahun 2007 BAB IV mengenai tanggung jawab sosial dan lingkungan disebutkan bahwa perseroan menjalankan kegiatan usahanya dibidang dan/atau berkaitan dengan sumber daya alam wajib melaksanakan tanggung jawab sosial dan lingkungan. Terdapat indikasi bahwa para investor tidak perlu melihat pengungkapan CSR yang dilakukan oleh perusahaan, karena terdapat jaminan yang tertera UU Perseroan Terbatas No. 40 Tahun 2007, bahwa perusahaan pasti melaksanakan CSR dan pengungkapanya, karena apabila perusahaan tidak melaksanakan CSR, maka perusahaan akan terkena sanksi sesuai dengan peraturan perundang-undangan.

\section{PENUTUP}

Simpulan

Berdasarkan analisis yang telah dilakukan maka simpulan yang dapat ditarik sebagai berikut:

1. Tidak terdapat pengaruh Corporate Social Responsibility Disclosure Index terhadap Price Book Value

2. Interaksi antara CSR dan prosentase Return on Asset berpengaruh signifikan terhadap Price Book Value

\section{Saran}

Berdasarkan hasil analisis pembahasan serta beberapa kesimpulan dan keterbatasan pada penelitian ini, adapun saran-saran yang dapat diberikan sebagai berikut:

1. Penelitian selanjutnya diharapkan menggunakan mnggunakan variabel lain sebagai variabel moderating hubungan antara pengungkapan tanggung jawab sosial perusahaan dan nilai perusahaan. Serta menggunakan seluruh perusahaan yang terdaftar di BEI sehingga sampel menjadi lebih luas. Penelitian selanjutnya diharapkan pula untuk menggunakan daftar pengungkapan sosial perusahaan berdasarkan standar GRI (Global Reporting Intiative)

2. Penelitian selanjutnya sebaiknya menggunakan framework item-item lain selain dari G3 Global Reporting Initiative untuk mengukur pengungkapan corporate social responsibility dan juga senantiasa diperbaharui acuan framework tersebut sehingga akan lebih sesuai dengan keadaan saat ini.

3. Bagi investor, untuk lebih mempertimbangkan aspek-aspek sosial dan lingkungan sehingga dalam melakukan investasi yang tidak terpaku pada ukuranukuran moneter 


\section{REFERENS}

Hadi, N. (2009). Interaksi Biaya Sosia, Kinerja Sosial, Kinerja Keuangan, dan Luas Pengungkapan Sosial "Uji Praktik Sosial Responsibility Perusahaan Go Public di Bursa Efek Indonesia. Disertasi. Program Pascasarjana Universitas Diponegoro.

Harahap, Sofyan S. (2012). Analisis Kritis Atas Laporan Keuangan. Jakarta: Rajawali Pers

Handriyani, Arik N. (2013). Pengaruh Corporate Social Responsibility terhadap Nilai Perusahaan dengan Profitabilitas Sebagai Variabel Moderating. Jurnal Ilmu \& Riset Akuntansi Vol. 2 No. 5 (2013).

Martono dan Harjito, Agus. (2011). Manajemen Keuangan. Yogyakarta: Penerbit Ekonisia
Munawir. (2011). Analisis Laporan Keuangan. Yogyakarta: Liberti.

Rahman, R. (2009). Corporate Social Responsibility Antara Teori dan Kenyataan. Yogyakarta: Media Presindo.

Rahmayanti, E. (2015). Harga Saham Perbankan Anjlok; Ini Penyebabnya. Tersedia di https://www.bareksa.com/id/text/2015 106/03/harga-saham-perbankan-anjlokini-penyebabnya/10656/news [diakses pada Rabu, 03 Juni 2015]

Ang, R. (2007). Buku Pintar Pasar Modal Indonesia (The Intelligent Guide To Indonesian Capital Market). Jakarta: Mediasoft Indonesia

Undang-Undang Nomor 40 Tahun 2007 tentang Perseroan Terbatas. 